\title{
ELISABETH KÜBLER-ROSS: UNA VIDA PARA UNA BUENA MORTE ${ }^{1}$
}

Cloves Amissis Amorim*

Susanne Schaup, jornalista e tradutora das obras de Kubler-Ross para o alemão, é a autora dessa breve biografia de uma longa e intensa vida. Pouco depois da publicação dessa obra, precisamente no mês de setembro de 1997, a biografada Elisabeth Kubler-Ross, deu a conhecer sua autobiografia "A roda da vida”. Portanto, para o leitor que desejar conhecer a trajetória existencial e o legado de Kubler-Ross, seria interessante começar pelo trabalho jornalístico de Schaup e concluir com as reflexões que a extraordinária psiquiatra suiça nos permite em sua autobiografia.

É imperativo destacar que Elisabeth Kubler-Ross, representa "uma reação do subjetivo, do pessoal, do intuitivo, do feminino, contra o público, o masculino, o econômico e o racional”, com essa afirmativa Klass (1982) explicita o que ele próprio definiu com um conflito entre dois sistemas de símbolos, ou seja: o da esfera privada pessoal e subjetiva frente ao da esfera pública, tecnológica e racional.

Wilma Torres (1998), esclarece que, como símbolo da esfera privada, subjetiva e feminina, Kubler Ross reinicia o movimento da ética e da dignidade do processo do morrer, um movimento que implica ouvir o paciente em suas necessidades como ser humano e atendê-lo em seus direitos.

Siempre digo que la muerte puede ser una de las más grandiosas experiências de la vida. Si se vive bien cada

Schaup, Susanne. Elisabeth Kübler-Ross: Una vida para una buena morte. Barcelona: Ediciones Martínez Roca, 1997.

* Professor do Curso de Psicologia da PUCPR e do Departamento de Enfermagem da UTP. Endereço para correspondência: Rua Dr. Pedrosa, 78/501B, 80420-120, Curitiba, Paraná.

\begin{tabular}{|l|l|l|l|l|l|}
\hline Psicologia em Estudo & DP/CCH/UEM & v. 5 & n. 1 & p. $145-148$ & 2000 \\
\hline
\end{tabular}


día, entonces no hay nada que temer (Kubler-Ross, 1997).

No prólogo, Sussanne Schaup informa que Kubler Ross, já havia publicado dezoito livros, traduzidos a vinte idiomas distintos e que exerceu influência na vida (eu diria também na morte) de inumeráveis pessoas.

Ao longo de seis capítulos, a autora procura apresentar uma visão ampla do pensamento e da obra da Dra. Kubler-Ross; no primeiro capítulo aborda "la conspiración del silencio"e relata como Klubler-Ross começou casualmente seu trabalho com pacientes terminais; as aulas e os depoimentos dos enfermos, a reação de médicos e enfermeiros e lembra uma de suas máximas "a atenção ao paciente terminal não pode ser deixada para amanhã, poderá ser demasiado tarde."

É surpreendente saber que o livro "Sobre a Morte e o Morrer", uma preciosidade da Tanatologia, foi escrito em apenas três meses, no horário das meia-noite às três da manhã.

Na página 26 transcreve a seguinte afirmação de Kubler-Ross:

Debemos reflexionar en profundidad sobre nuestra propia postura frente a la muerte, antes de poder sentarnos junto al paciente, sin miedo y con serenidad (p.26)

Falando sobre como vencer o próprio medo da morte, para que profissionais pudessem ser mais sensíveis com os pacientes moribundos, começou nos anos setenta, uma intensa atividade internacional pronunciando conferências e dirigindo seminários. Schaup, conclui o primeiro capítulo com a seguinte citação:

Pronto dejaré de viajar. He cumplido com lo que estaba destinada a hacer. He podido funcionar como catalizador, y he procurado que quede claro en nuestra conciencia que sólo podemos vivir de verdad y amar la vida si somos conscientes en todo momento de que somos seres efímeros. No necesito mencionar que he aprendido estas lecciones de mis pacientes agonizantes, quienes se dieron cuenta a raíz de su sufrimiento y de su muerte de que solamente disponemos del ahora: "Así pues, 
disfrútalo a fondo y descubre que és lo que te mueve, pues ningun outra persona puede hacerlo en tu lugar (p.29).

No segundo capítulo, retrata os principais momentos da vida de kubler-Ross, fala dos pais, das irmãs, da experiência do pós-guerra e enfatiza a experiência como psiquiatra no Manhattan State Hospital.

As fases do morrer, mais especificamente as cinco fases (negação, raiva, barganha, depressão e aceitação) são descritas no terceiro capítulo e afirma que essas fases seguem sendo úteis como "modelo de pensamento" e que necessariamente não tem que cumprir-se na prática, ressalta ainda que essas fases não se dão necessariamente na mesma ordem, mas que podem ocorrer de formas distintas.

No capítulo quatro intitulado "Los Talleres", a autora nos comenta as experiências de Kubler-Ross nos incontáveis seminários que realizou nos Estados Unidos e em todos os continentes, com o título "Vida, morte e transição", com duração de cinco dias apresentava as seguintes características:

Nuestro objetivo, la finalidade de estas reuniones de cinco días, radica en ayudar a los participantes a aproximarse a los más profundos dolores, miedos y sentimientos de culpa y verguenza que han venido reprimiendo durante largo tiempo y, de esta manera, solucionar todas las cuestiones pendientes. Les enseñamos básicamente lo que normalmente tratan de hacer los enfermos en fase terminal: "hacer limpieza" de todo lo que no han solucionado, a fin de que no les quede dentro ninguna negatividad y puedan vivir literalmente hasta su muerte com un sentimiento de paz, alegría, aceptación y darse a sí mismos y a los demás (p.82).

"El Mensaje”, capítulo cinco, aborda os grupos, suas experiências terapêuticas e a perspectiva teórica denominada Transpessoal. De acordo com Schaup, não é casualmente que a obra de Kubler Ross tenha surgido numa época e num lugar determinado. O movimento para o desenvolvimento do potencial humano, nascido na Califórnia nos anos sessenta e que culminou nos anos setenta, compôs o grande movimento transpessoal que buscava unir a ciência à mística em uma busca comum da verdade. Destaca ainda neste capítulo, um aspecto do legado de Kubler Ross: 
Para aquellos que se esfuerzan por comprender la muerte, èsta representa una fuerza altamente creativa. Los valores espirituales más elevados pueden desprenderse del estudio y la reflexión sobre la muerte. [...] Espero poder transmitir un mensaje importante a mis lectores: que la muerte no tiene por qué ser un fenómeno catastrófico y destructivo. Más bien se puede considerar una de las partes más constructivas y creativas de la cultura y de la vida (p.99).

Finalmente, no capítulo seis, "Más allá de nuestro mundo y nuestro tiempo, de acordo com a autora, se apresenta o que realmente tem mais importância para a própria Elisabeth Kübler-Ross. Entre muitas conclusões, destaca que "la muerte no es outra cosa que una transición hacia outro estado de la consciencia”. Prossegue apresentando experiências místicas vivenciadas por Kubler Ross, sua concepção do amor incondicional, seus ensinamentos sobre a morte digna e a vida autêntica. Na página 120, Susane Schaup, comenta sobre uma foto de Kubler -Ross, "Su rostro está marcado por profundas arrugas. La raíz de la nariz y la frente son la expresión de un carácter fuerte. Los ojos tienen una mirada valiente, sabia e algo triste. Que saber sería aquel que no há visto los abismos? Sólo este tipo de conocimiento es sabiduría [...].

Portanto, estamos diante de um livro agradável de ler, intrigante, onde a autora demonstra sua capacidade de investigação jornalística e reflexão, conhecimento seguro sobre a vida de Kubler Ross e estratégia elegante de redação. E confortante ler a biografia de uma mulher estudiosa, pesquisadora tenaz, corajosamente provocativa do estabelecido e ternamente solidária com o ser humano no seu momento mias frágil e misterioso, o da sua morte.

Não posso privar-me de alegria e contentamento diante desta obra, e os convido a compartilhar comigo esta sensação lendo este livro.

\section{REFERÊNCIAS BIBLIOGRÁFICAS}

Klass, D. Elizabeth Kübler-Ross and the tradition of the private sphere: na analysis of symbols. In: Omega, 12(3), 241-267, 1091-82. 